\title{
Emerging fungal contaminants isolated and identified from raw fennel seeds
}

\author{
Chinju Merin Abraham ${ }^{*}$, Tincy Mary Thomas ${ }^{2}$ \\ ${ }^{1}$ Department of Botany, Catholicate College, Pathanamthitta, India \\ ${ }^{2}$ Department of Botany, Catholicate College, Pathanamthitta, India \\ *Corresponding Author: First author- chinjujoby@gmail.com, Tel.:+91-9846129284
}

Available online at: www.isroset.org

Received: 21/May/2018, Revised: 30/May/2018, Accepted: 17/Jun/2018, Online: 30/Jun/ 2018

\begin{abstract}
The present investigation entitled "Emerging fungal contaminants isolated and identified from raw fennel seeds" recorded the diversity of surface contaminant fungi from 144 fennel seeds of different A/C and non-A/C hotels of town area of Pathanamthitta district of Kerala, which were cultured on PDA medium. All fungal species were identified on the basis of their morphological and microscopic characteristics and it includes Aspergillus niger, Aspergillus fumigatus, Chrysonilia sitophila, Mucor sp., Rhizopus sp., Cercospora sp. and Cylindrocarpon sp. The study revealed its colonization frequency, counted the fungal colony numbers, determined the percentage of different fungal isolates and finally compared the $\mathrm{A} / \mathrm{C}$ and non- $\mathrm{A} / \mathrm{C}$ seed contaminants. And from the study, it was clear that samples from non-A/C hotels shows maximum fungal growth than A/C hotels. These emerging fungal contaminants can cause serious pathogenic conditions such as aspergillosis, zygomycosis, occupational asthma etc.
\end{abstract}

Keywords - Fungal contaminants, Fennel seeds, Pathanamthitta, PDA medium, Colonization frequency, Aspergillosis

\section{INTRODUCTION}

The contamination of spices by fungus is a serious issue being faced nowadays. Many spices are traditional herbs and medicinal indigenous ingredients since a long time, herbal medicines have been used in the management of several diseases [1]. Fennel seed is a common south-Indian spice that has serious issues in relation with its fungal contamination. Fennel plants are biennial or perennial aromatic herbs with anticancerous property $[2,3]$.

Many species of fungi are responsible for the contamination of the fennel crops before harvest or during storage by the production of aflatoxin [4]. Aflatoxins are acutely toxic, immunosuppressive, mutagenic, teratogenic and carcinogenic compounds. Spices on storage are heavily contaminated with the xerophilic storage moulds and bacteria [5]. The most frequent fungal contaminant of spices is the species from Aspergillus and Penicillium [6]. Although spices are present in foods in small amounts, they are recognized as important carriers of microbial contamination mainly because of the conditions in which they were grown, harvested and processed [7]. Eating contaminated raw spices may lead to the intake of many mycotoxins [8].

It is a common practice, particularly in the South-Indian culture to chew raw fennel seeds after meals and these spices being the part of our Indian food culture and also it aids in digestion. It is necessary to create awareness to public about the improper handling of fennel seeds that leads these seeds as a host for several pathogenic organisms. Thus the present work focuses on the harmfulness on consuming contaminated raw fennel seeds. From the colonization frequency and other datas analysed, it was clear that all the seeds collected were heavily contaminated by the fungal pathogens. The mycotoxins produced by these pathogens can cause serious ill-effects like aspergillosis, zygomycosis, occupational asthma, mucormycosis etc.

\section{II .MATERIALS AND METHODS}

Plant material- Raw seeds of Foeniculum vulgare Miller [9]

Systematic position

Kingdom: Plantae

Division : Angiospermae

Class : Dicotyledoneae

Order : Umbellales

Family : Apiaceae

Collection of seeds sample:

For the present investigation, raw fennel seed samples were collected from six different $\mathrm{A} / \mathrm{C}$ and non- $\mathrm{A} / \mathrm{C}$ hotels of town area of Pathanamthitta district, uniformly during the month of March-April 2017. Each sample were collected in a separate sterile polythene bags and brought to the laboratory for further studies. 
Inoculation of seed sample to Potato Dextrose Agar (PDA) Medium [10]:

A total of 144 fennel seeds were inoculated and cultured to PDA plate immediately after collection (8 seeds per plate) at equal distance. Triplicates of plates were prepared to confirm the results. The plates were sealed with parafilm and incubated for 7 to 10 days at room temperature for fungal growth.

Isolation and Identification of the fungal genera:

Most of the fungal growth was initiated on fourth and fifth days of inoculation. The fungi that grew out from the segment were periodically exalted and sub-cultured for pure culture maintaining. Identification of different fungi was done with help of slides prepared by direct mount from the culture. For preparation, hyphae taken from the pure culture were stained using lactophenol cotton blue. Then examined under microscope and photographed. Fungal contaminants were identified according to their macroscopic and microscopic characteristics such as colour of the culture, morphology of fruiting body and spore morphology. The identification was confirmed with the help of authentic manuals [11]

\section{Analysis of data:}

Total numbers of different fungal colonies were documented by counting the specific fungal morphology. Colonization frequency of surface contaminant fungi and the Percentage of occurrence of fungal contaminant of fennel seeds were calculated [12].

\section{RESULT}

Through the study, we isolated and identified different fungal species which causes serious ill-effects to human health. These were identified as Aspergillus niger, Aspergillus fumigatus, Chrysonilia sitophila, Mucor sp., Rhizopus sp., Cercospora sp. and Cylindrocarpon sp.

A total of 7 species belonging to 6 genera, which belongs to the sub-divisions Ascomycotina, Zygomycotina and Deuteromycotina were recovered and identified from the samples using PDA medium method (Table 2). Further it was clear that all the fennel seed samples were contaminated with fungal pathogens (Table 1).

Colonization frequencies of different fungal isolates were calculated, from which it was observed that among $\mathrm{A} / \mathrm{C}$ and Non A/C seed samples, Aspergillus niger (87.5\%), with highest colonization frequencies. The dominant fungal species is Aspergillus niger with 66 colonies. The second dominant fungal species is Aspergillus fumigatus with 42 colonies. The least dominant colony obtained was Mucor sp with 7 colonies. The data also reveals that samples from non$\mathrm{A} / \mathrm{C}$ hotel have more number of fungal colonies than that of the A/C hotel (Table $3 \&$ Graph 1). From the colony number, we calculated the percentage of fungal occurrence. It was clear that Aspergillus niger and Mucor sp. were the most occurred and least occurred respectively

Table 1- List of fungus identified from the sample (+: Presence, - : Absence)

\begin{tabular}{|c|c|c|c|c|c|c|c|c|}
\hline $\begin{array}{l}\text { Fungal } \\
\text { isolates. }\end{array}$ & $\begin{array}{l}\text { A/ } \\
\text { C } \\
\text { H- } \\
1\end{array}$ & $\begin{array}{c}\text { A/ } \\
\text { C } \\
\text { H- } \\
2\end{array}$ & $\begin{array}{l}\text { A/ } \\
\text { C } \\
\mathrm{H}- \\
3\end{array}$ & $\begin{array}{l}\text { Total } \\
\text { no.of } \\
\text { occuren } \\
\text { ce }\end{array}$ & $\begin{array}{l}\text { No } \\
\text { n- } \\
\text { A/ } \\
\text { C } \\
\text { H-1 }\end{array}$ & $\begin{array}{l}\text { No } \\
\text { n- } \\
\text { A/ } \\
\text { C } \\
\text { H- } \\
2\end{array}$ & $\begin{array}{l}\text { No } \\
\text { n- } \\
\text { A/ } \\
\text { C } \\
\text { H- } \\
3\end{array}$ & $\begin{array}{l}\text { Total } \\
\text { no.of } \\
\text { occuren } \\
\text { ce }\end{array}$ \\
\hline $\begin{array}{l}\text { Aspergillus } \\
\text { niger }\end{array}$ & + & + & + & 3 & + & + & + & 3 \\
\hline $\begin{array}{l}\text { Aspergillus } \\
\text { fumigatus }\end{array}$ & + & + & - & 2 & + & + & + & 3 \\
\hline Rhizopus & - & - & + & 1 & + & + & + & 3 \\
\hline $\begin{array}{l}\text { Chrysonilia } \\
\text { sitophila }\end{array}$ & + & + & - & 2 & + & + & + & 3 \\
\hline Mucor & - & - & + & 1 & + & - & - & 1 \\
\hline Cercospora & - & - & + & 1 & + & + & - & 2 \\
\hline $\begin{array}{l}\text { Cylindrocar } \\
\text { pon }\end{array}$ & + & - & - & 1 & + & - & + & 2 \\
\hline
\end{tabular}

Table No. 2- List of fungal isolates with its sub-division.

\begin{tabular}{|l|l|l|}
\hline SI.No & Sub-division & Fungal isolates \\
\hline 1 & Ascomycotina & Aspergillus niger \\
\cline { 3 - 3 } & & Aspergillus fumigatus \\
\cline { 3 - 3 } & & Chrysonilia sitophila \\
\cline { 3 - 3 } & & Cylindrocarpon sp. \\
\hline 2 & Zygomycotina & Rhizopus sp. \\
\cline { 3 - 3 } & & Mucor sp. \\
\hline 3 & Deuteromycotina & Cercospora sp. \\
\hline
\end{tabular}

Table No. 3. Total colony number of fungal isolates from $\mathrm{A} / \mathrm{C}$ and non- $\mathrm{A} / \mathrm{C}$ samples.

\begin{tabular}{|c|l|c|c|c|}
\hline $\begin{array}{l}\text { SI. } \\
\text { No }\end{array}$ & Fungal isolate & $\begin{array}{l}\text { Fungal } \\
\text { colony No: } \\
\text { (A/C sample) }\end{array}$ & $\begin{array}{c}\text { Fungal colony } \\
\text { No: (Non-A/C } \\
\text { sample) }\end{array}$ & $\begin{array}{c}\text { Total } \\
\text { colonies }\end{array}$ \\
\hline 1 & Aspergillus niger & 15 & 51 & 66 \\
\hline 2 & $\begin{array}{l}\text { Aspergillus } \\
\text { fumigatus }\end{array}$ & 9 & 33 & 42 \\
\hline 3 & Rhizopus sp. & 8 & 24 & 32 \\
\hline 4 & Mucor sp. & 2 & 5 & 7 \\
\hline 5 & $\begin{array}{l}\text { Chrysoniliasitophila } \\
\text { sp. }\end{array}$ & 5 & 21 & 26 \\
\hline 6 & Cercospora sp. & 3 & 15 & 18 \\
\hline 7 & Cylindrocarpon sp. & 2 & 11 & 13 \\
\hline
\end{tabular}


Graph-1.Comparison of total colony number from $\mathrm{A} / \mathrm{C}$ and non-A/C seed samples

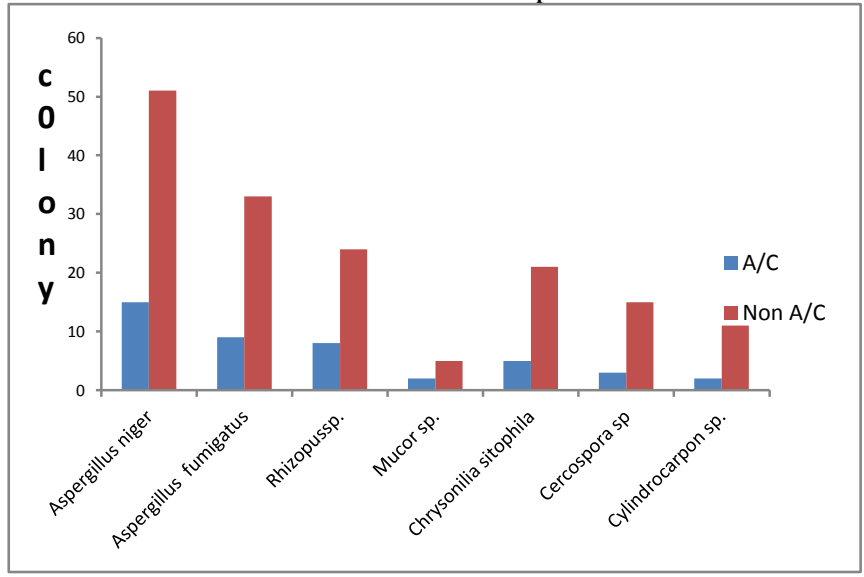

\section{DISCUSSION}

The present investigation entitled "Emerging fungal contaminants isolated and identified from raw fennel seeds" documented the different fungal contaminants and its harmful effects on human health. Several pathogens were isolated which causes serious pathogenic conditions such as aspergillosis, zygomycosis, mucormycosis, occupational asthma etc. Aspergillosis is an infection caused by Aspergillus sp, a common mold that lives indoors and outdoors. Most people breathe in Aspergillus spores every day without getting sick. However, people with weakened immune systems or lung diseases are at a higher risk of developing health problems due to Aspergillus.

The most common etiologic agents of zygomycosis include member of the genera Rhizopus and Mucor. These organisms have taken an advantage in immune-compromised patients which also cause high mortality rate. Mucormycosis is the major infection caused by Mucor sp. The major risk factors for mucormycosis include uncontrolled diabetes mellitus in ketoacidosis, other forms of metabolic acidosis, treatment with corticosteroids, organ or bone marrow transplantation, burns, malignant hematologic disorders etc. This emerging fungal pathogen is also responsible for zygomycosis and several other allergic problems in immunosuppressed patients.

Our sampling (144seed samples) and further studies indicates that the fungal pathogens were widely distributed in the study area.

\section{CONCLUSION}

Spices occupy a prominent place in the traditional culinary purposes and are indispensable part of daily diets of millions of people all over the world. They are essentially flavoring agents used in small amounts and are reported to have both beneficial and antimicrobial properties, if properly stored
[13]. This reveals the importance of the present work and through the study; we isolated and identified seven different fungal contaminants belonging to six genera which cause serious ill-health to life. The major isolates were emerging fungal pathogens such as Rhizopus sp. and Mucor sp. which cause diseases such as zygomycosis and mucormycosis. The most dominant fungal pathogen that we isolated from both $\mathrm{A} / \mathrm{C}$ and non-A/C seed sample was Aspergillus niger, which is responsible for aspergillosis. Although most human diseases are caused by bacteria or viruses, fungal pathogens are a major cause of death among immuno-suppressed patients. All these fungal pathogens are emerging at an alarming rate world-wide and pose a significant threat to wild-life health [14]. So it is necessary to create awareness to public about the improper handling of spices that leads it as a host for several pathogenic organisms. Further, a detailed study is necessary in this aspect to elucidate more about the emerging fungal pathogens.

\section{REFERENCE}

[1]. K. Suvarna, S. Nandini, "Effect of Indigenous foods on blood glucose level of Type-2 diabetc patients", International Journal Of Scientfic Resarch In Biological Science, Volume.2, Issue.5, pp.1, 2015.

[2]. E.A. Weiss, "Spice Crops", CABI, Wallingford, pp.356-360, 2002

[3]. P. Anand, A. Kunnumkara, C. Sundaram, K. Harikumar, S. Tharakan , O. Lai, B. Sung, B. Aggarwal, "Cancer is a preventable disease that requires major lifestyle changes", Pharm. Res., 25, pp. 2097-116, 2008.

[4]. J. Yu, Whitelaw, W.C. Nierman, D. Bhatnagar, T. E Cleveland, "Aspergillus flavus expressed sequence tags for identification of genes with putative roles in aflatoxin contamination of crops". FEMS Microbiol. Lett. 237, pp. 333-340, 2004.

[5]. B. Romagnoli, V. Menna, N. Gruppioni, C. Bergamini, "Aflatoxins in spices, aromatic herbs, herbs-Teas and medicinal plants marketed in Italy", pp. 697-701, 2007.

[6]. G. Dimic, S. Krinjar, M.V. Dosen-Bogic Evic, "Dance, a potential producer and sterigmatocystin in spices", Tehnol. Mes. 41(4-6): pp. 131-137, 2000.

[7]. S.D. Kocic-Tanackov, G.R. Dimic, D. Karalic, "Contamination of spices with moulds potential producers of sterigmatocystine". APTEFF, 38: pp. 29-35, 2007.

[8]. Z. I. El-Gali, "Detection of fungi associated with some spices in original form", Glob.J.Sci.Res. 2(3): pp.83-88, 2014.

[9]. K.M. Mathew,"An excursion flora of central Tamilnadu,India”, Oxford and IBH Publishing, pp. $225,1991$.

[10].F.P Downes, K. Ito, "Compendium of Methods for the microbiological examination of foods", $4^{\text {th }}$ Ed., APHA, Washington,D.C, 2001

[11]. Watanabe, Tsuneo, "Pictorial atlas of soil and seed fungi, Morphologies of cultured fungi and key to species", $2^{\text {nd }}$ edition, CRC Press, Washington D.C, pp. 121-125, 2002.

[12]. T.S. Suryanarayanan, G. Venkatesan, T.S Murali, "Endophytic fungal communities in the leaves of tropical forest trees: Diversity and distribution pattern", Current sciences, 85(4): pp.489-492, 2003.

[13]. O.O. Atanda, I. Akpan, F. Oluwafemi, "The potential of some spice essential oils in the control of A. parasiticus CFR 223 and aflatoxin production", pp.1-7, 2006. 
[14]. M.C.Fischer, "Emerging fungal threats to animal, plant and ecosystem health". Nature 484, 186-94, doi: 10.1038/nature 10947, 2012.

\section{AUTHORS PROFILE}

Chinju Merin Abraham, awarded her M.Phil Botany and currently working as a Lecturer in Department of Botany, Catholicate College, Pathanamthitta, Kerala, India. Tincy Mary Thomas awarded her M.Sc Botany and currently pursuing as a research scholar in Department of Botany, Catholicate College, Pathanamthitta, Kerala, India. 